The Poems of Meleager 



\section{The Poems of}

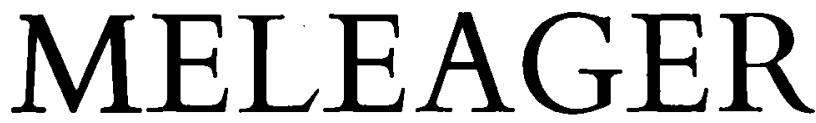

Verse translations by Peter Whigham Introduction and literal translations by Peter Jay

University of California Press Berkeley and Los Angeles 
University of California Press

Berkeley and Los Angeles, California

ISBN: 0- $520-03003-6$

Library of Congress Catalog Card Number: 75-7196

Verse translations copyright (C) Peter Whigham 1975

All other material copyright (C) Peter Jay I975

Printed in Great Britain

Bound in the United States of America 